\title{
Don Kazaklarının Azak’ı İşgalleri (1637-1642)
}

\author{
Don Cossacks’ Invasion Of Azov (1637-1642)
}

\section{Sinan YÜKSEL ${ }^{*}$}

\section{$\ddot{O} z$}

Osmanlı Devletinin, Kuzey Karadeniz'de Azak ve çevresindeki egemenliğinin simgesi konumunda bulunan Azak Kalesi, bölgede Osmanlı Devleti için bir güven unsuruydu. Bununla birlikte kale, Ruslar ve Kazaklar için tehdit ve Karadeniz yönünde önemli bir engel durumundaydı. Kazakların Azak'ı işgalleri, Rusların Osmanlı Devleti ve Kırım Hanlığ ile karşı karşıya gelmelerine neden olmuştur. Kazakların bu işgali kendi bilgileri dışında yaptıkları yönünde açıklamalarda bulunarak Osmanlı Devleti ve Kırım Hanlığının tepkisini önlemeye çalışan Ruslar, Kazakların Azak'l ellerinde tutmalarl avantajindan yararlanmaktan da çekinmemişlerdir. Azak'l ellerinde tuttukları müddetçe Kazaklara mühimmat ve para yardımında bulunan Ruslar, Osmanlı Devletinin Azak'l geri almak üzere yapmış oldukları saldırı sonrasında oldukça yıpranan kaleyi Kazaklardan teslim almaları yönündeki Kazakların teklifini geri çevirmişlerdir. Ruslar, bu politikalarıla Karadeniz yönünde aktif bir siyaset içinde olmadıklarını ortaya koymuşlardır.

Anahtar Kelimeler: Ruslar, Don Kazaklarl, Azak Kalesi, Karadeniz

\section{Abstract}

Azak Castle, which is the symbol of the Ottoman State sovereignty in Azak and its around in the Northern Black Sea, was a safety fact for the Ottoman State in the region. However, the castle was a threat for Russians and Cossacks and an important barrier in the direction of the Black Sea for them. Cossacks' invasion of Azak resulted in Russians' encounter with the Ottoman State and the Crimean Khanate. Russians declared that Cossacks made this invasion without their information and tried to prevent response of the Ottoman State and the Crimean

\footnotetext{
* Okutman, Zonguldak Karaelmas Üniversitesi, sinanyksel@yahoo.com
} 
Khanate, yet they did not hesitate to take the advantage of Cossacks' retain of Azak. As long as Cossacks retained Azak, Russians subsidized Cossacks with ammunition and money; and, rejected Cossacks' offer for committing the castle, which was frayed after the Ottoman attack for retrieval. Russians demonstrated not following an active policy for the Black Sea with this manner.

Key Words: Don Cossacks, Russians, Azak Castle, Black Sea

\section{Giriş}

Fatih Sultan Mehmet döneminde Karadeniz'in kuzeyinde yapılan fetihlerden biri de 1475'te ele geçirilen Azak Kalesi'ydi. Bölgede yayılmacı ve saldırgan bir politika izlemeyen ${ }^{1}$ Osmanlı Devleti'ne Azak Kalesi, Kırım ve Nogay Tatarları ile Kuzey Kafkasya'nın Müslüman halklarını dizginleme ve bastırabilme olanağı sağlıyordu². Bunun yanı sıra Azak Kalesi, Don Kazaklarının ve Rusların güneye Azak Denizi ve Karadeniz'e çıkmalarına da ciddi anlamda engeldi. Osmanlıların burayı askeri üs olarak kullanıp kendileri üzerine saldırılarda bulunma ihtimali Rusların ve Kazakların üzerlerinde önemli bir bask1 hissetmelerine neden oluyordu. Kale Osmanlılarda olduğu sürece kendilerini güvende hissetmeleri de zordu. Kazaklardan Moskova'ya gönderilmiş olan mektuplar da bu durumu ortaya koyuyordu. Mektupların birinde Kazakların Azaklılardan çektikleri sıkıntılar şu şekilde anlatılmaktaydı: “...ve sayın hükümdarımız o adi Azaklılar bizler ve kardeşlerimizi yaşadığımız çadırlarda, nehirlerde, kamışların arasında ve geçişlerde yakalıyor ve deniz aşırı ülkelere kalyonlarda kürek çekmek için satıyor, büyük hüzün yaşatıyor, özgürlügümüzü ellerimizden alıyor”3. Don Kazakları, Azak Kalesini kendileri için nasıl tehdit olarak görüyorlarsa, Azak Kalesi için de en önemli tehdit Don Kazaklarıydı. Osmanlıların Kuzey Karadeniz'de Azak ve çevresindeki hâkimiyetinin simgesi konumunda bulunan kale, 16. yüzyılın ikinci yarısına kadar nispeten tehlike ve baskınlardan uzak kalmışsa da yüzyılın ikinci yarısından itibaren Don Kazaklarının saldırılarına uğramaya başladı ${ }^{4}$.

Akdes Nimet Kurat, Türkiye Ve İdil Boyu (1569 Astarhan Seferi, Ten-İdil Kanalı ve XVIXVII yüzyıl Osmanlı-Rus Münasebetleri), Ankara 1966, s. 48-49.

2 Yu. A. Tihonov, “Azovskoye Sideniye", Voprosi Istorii, No:8, Moskva Avgust 1970, s. 100.

3 M. Popov, "Azovskaya Oborona (Stranitsa iz İstorii Donskogo Kazaçestva XVII v.)", İstoriçeskiy Jurnal, No:3, Moskva 1995, s. 47.

4 Kurat, s. 52. 
Don Kazakları ${ }^{5}$, Rusların köylülere uyguladığı ağır kölelik düzeninden kaçarak, 15. yüzyılın sonları ve 16. yüzyılın başlarından itibaren Don bölgesinin ormanları ve bozkırlarını mekân edinmeye başladı. Don bölgesine Rusya'daki meşru idareye karşı gelen, disiplinden uzak, tehlikelerden korkmayan, feodal düzenden kaçan cesur ve güçlü insanlar akın ediyordu ${ }^{6}$. Özgürlüklerine son derece düşkün olan bu insanlar geçimlerini balıkçılık ve yağmalarla kazanıyorlard1 ${ }^{7}$. Göçebeler ve Osmanlı kuvvetleriyle sürekli yapılan çatışmalar, Don Kazaklarını usta ve deneyimli savaşçılar haline getiriyordu. Askeri seferlerde sadece Kazaklar yer almıyordu. Her bahar Don bölgesine, Rusya'dan erzak ve zanaat eşyası satışı yapan tüccarlar, demirciler, doğramacılar ve balıkçılar iş bulma amacıyla geliyordu. Tüccarlar, gemi kürekçileri, zanaatçılar "zipun" elde etmek amacıyla yani savaş ganimeti için Kazaklarla beraber Kırım ve Osmanlı sahillerine doğru gidiyordu ${ }^{8}$. Don Kazakları, Don Nehrinden aşağılara inerek, Müslüman halka saldırıp zarar vermelerinin yanı sıra Rus tüccar ve elçilerini de yağma etmekten çekinmiyorlard1 ${ }^{9}$.

16. yüzyılın ikinci yarısından itibaren önemli bir güç haline gelen Kazaklar, tahıl, silah, barut ve diğer önemli ihtiyaçlarını karşılamak için Rusya'ya yakınlaşmışlar ve IV. İvan zamanında Rusya'nın emri altına girmişlerdi $^{10}$. Moskova Hükümeti ile Rusya'nın imtiyazlı sınıflarının Don Kazaklarına karşı tutumu ikili nitelikteydi. Bir taraftan kaçaklar için bir barınak olan ve sosyal tehlikenin ocağı olan Don bölgesi onları oldukça endişelendiriyordu. Diğer taraftan Tatar baskınlarının başarılı bir şekilde geri püskürtülmesi için Don Kazakları önemliydi. Tatarların saldırılarına karşı Moskova Hükümeti,16. yüzyılın ikinci yarısından itibaren Kazakları bekçilik hizmetleri ve keşif amaçlı olarak işe almaya başladı. 16. yüzyılın ikinci yarısından itibaren Kazak şehirleri giderek güçleniyor ve Kazakların askeri önemi de artıyordu. Moskova Hükümeti tarafından Don Kazaklarına özel imtiyazlar tanıyan, onların güneydeki şehirlerde vergisiz ticaret yapmaları izninin yanı sıra, onlara yıllık maaş olarak, para, ekmek, kumaş, barut,

5 Kazaklık terimi öncelikli olarak Türk Tatar kültürüne bağlı Müslümanlar için kullanılmıştır. Altınordu, Kırım ve Astarhan Hanlarının otoritelerini tanımayıp, geniş step bölgelerine yerleşmiş disiplinden uzak insanlara bu isim verilmişti. Sonrasında bu isim Rusya ile Litvanya-Lehistan'daki devlet düzenine karş1 gelip geniş step bölgelerine yerleşenler için de kullanılmıştır. Halil İnalcık, "Osmanl1-Rus İlişkileri”, Türk Rus İlişkilerinde 500. Yll (1491-1992), (Ankara 12-14 Aralık 1992), Ankara 1999, s. 31-32.

6 Tihonov, s. 101.

7 Kurat, s. 53.

8 Tihonov, s. 101.

9 Kurat, s. 53.

10 A.P. Novosiltsev, "XV. Yüzyı1 ile XVI. Yüzyılın İlk Yarısında Rus-Türk İlişkileri”, Türk Rus İlişkilerinde 500. Yll (1491-1992), (Ankara, 12-14 Aralık 1992), Ankara 1999, s. 78. 
kurşun yardımı yapılıyordu. Don bölgesine yerleşen kaçaklar, özgür insanlar olarak kabul ediliyor ve onların tüm işleri ile dış işleri idaresi ilgileniyordu ${ }^{11}$. Don Kazaklarının Rusya hizmetine girmeleriyle Tatarlar üzerine ve güneye yaptıkları akınlar da arttı. Rus ve Çerkeslerle birlikte 1559'un ilkbaharında Azak Kalesi'ni kuşatan Don Kazakları, 1572, 1580 ve 1593'te Azak ve çevresine ciddi zararlar vererek geri çekildiler ${ }^{12}$.

Kazakların, Azak Kalesi ve Osmanlı topraklarına yaptıkları akınlar 17. yüzyılda da devam etti. 17. yüzyılın başlarında Kerç ve çevresine akınlar düzenleyen Don Kazakları ${ }^{13}$, 1614 yılında Zaporog Kazaklarıyla birlikte Sinop'a; 1615 'te de Trabzon'a büyük zararlar vererek geri döndüler ${ }^{14}$. Don Kazaklarının bu ve sonrasında, Kırım ve Osmanlı topraklarına yaptıkları akınlar Rusya'yı, Osmanlı Devleti ve Kırım Hanlığı'na karşı zor durumda biraktı.

Bunun üzerine Moskova Hükümeti, 10 Mart 1623'te Moskova asilzadesi M.V. Beloselskiy ile Don Kazaklarına gönderdiği mektupta Osmanlı Devleti'ne ve Kırım'a karşı olan tutumunu, Don kuvvetleri komutanına gayet açık bir dilde şu şekilde anlattı: " Sultan ve Kırım Hanı geçen yıllardan beri bizim düşmanımız büyük Rus Devletinin yıkıcısı Lehistan Kralı Siguzmund ile savaşmaktadırlar... Onlar ile Rus Hükümeti daimi bir dostluk halinde yaşamaktadırlar... Fakat Kırım Hanı ile Osmanlı Sultanı Kazakların onların topraklarına saldırmalarından şikâyet etmekte, bunlara son verilmesini istemekte ve aksi takdirde Tatar akınlarına yol verecekleriyle bizi tehdit etmektedirler". Mektupta Don Kazaklarının hükümetin menfaatlerine aykırı hareket ettikleri, şayet Tatarlar Rus topraklarına saldırırlarsa, dökülen kan ve kavga için mesuliyetin Kazaklara ait olacağ belirtildi. Moskova Hükümeti'nin göndermiş olduğu bu mektuba rağmen, Kazaklar Kırım ve Osmanlı topraklarına saldırılarına devam ettiler. 1625 yılının Ekim başlarında Moskova'ya gelen Kazakların Atamanı A. Storogo, sorguya çekilerek, Don Kazaklarının barışı koruma hakkında Çar'ın emirlerini ihlal ettikleri gerekçesiyle suçlu ilan edilerek arkadaşlarıyla birlikte Bekoozero adındaki bir yere sürgün edildi. 25 Ekim'de de Don Kazaklarına, Çarın emirlerini yerine getirmemekle, Kırım ve Osmanlı Devleti topraklarına saldırarak barışı bozmakla, Rus Hükümetine gereken

Tihonov, s. 101.

12 A. A. Novoselskiy, Borba Moskovskogo Gosudarstva S Tatarami V Pervoy Polovine XVII. Veka. Moskva, 1948, s. 41; B. V. Çebotarev-L. M. Kazakova, "Azov-Gorod Krepkiy", Voprosi Istorii, No:8, Moskva 1967, s. 211; Kurat, s. 160-161.

13 Novoselskiy, s.47.

14 Katip Çelebi, Tuhfetü'l-Kibar Fi Esfari'l Bihar, İstanbul 1329, s.106; B.V.Lunin, Azovskaya Epopeya (1637-1641), Moskva 1988, s. 10-11. 
yardımı yapmamakla suçlayan ve derhal başıbozukluğa son vermeleri gerektiği ile ilgili tekrar yazılı bir emir gönderildi. Bu emirde ayrıca Çar Boris Godunov iktidarı zamanında Kazakların, Rus Hükümetinin merkez şehirlerinden uzaklaştırıldıkları hatta kenar șehirlere bile girmelerinin yasaklandığı hatırlatılarak, şu an merkez şehirlere girebildikleri ve ticaret yapabildikleri yazılmıştır. Kazakların bundan böyle hükümet emirlerine aykırı ve diğer hükümetlerle barışı bozacak hareketlerde bulundukları takdirde tekrar haklarının geri alınacağ 1 bildirildi ${ }^{15}$.

Kırım ve Osmanlı topraklarına saldırıları yasak eden emirler 1627 ve 1628 'de iki defa olmak üzere tekrarlandığı halde Kazaklar bu emirlere uymayarak saldırılarına devam ettiler. Kazakların bu saldırıları Kırım ve İstanbul'dan gelen elçiler tarafindan hep şikâyet konusu edildi. Kazaklardan bu faaliyetlerinin durdurulması istendi. Moskova Hükümeti ise her defasında, Kazakların kendi başlarına hareket ettiklerini ve kendilerini dinlemediklerini söyleyerek, sorumluluğun Don Kazaklarına ait olduğunu bildirdi $^{16}$. Rusya'nın 1632 ile 1634 yılları arasında Lehistan ile yapmış olduğu mücadeleden başarısızlıkla ayrılması, güneydeki barışın korunmasını daha da önemli hale getirdi. Smolensk Savaşı sonrasında Lehistan ile sınırın Moskova'dan sadece 200-250 km uzaklıkta olması Rusya üzerinde ciddi bir baskı oluşturuyordu ${ }^{17}$. Rusya, bu dönemde Osmanlılar ve Kırımlılar ile bir sorun yaşamak istemediğinden dolayı Don Kazaklarına, Azak'a ve Kefelilere dokunmamalarını, denize çıkmamalarını, sultana ait yerlere zarar vermemelerini ve çarın sultan ile aralarının açılmasına sebep olacak hareket ve faaliyette bulunmamalarını istedi. Moskova'nın bu isteklerine rağmen Kazaklar, 1634 yılının Temmuz ayında deniz yolu ile Kerç şehrine kadar gelerek yağmalarda bulundular. Ekim ayında da Zaporog Kazakları ile birlikte Azak'ın kuşatılmasına katıldılar ${ }^{18}$. Don Kazaklarının bu faaliyetlerinden dolayı IV. Murat, Rusya'ya tehditkâr bir mektup gönderdi. IV. Murat mektubunda, Ruslardan daha önce yapmış oldukları anlaşmaya uyarak, Don Kazaklarının denize çıkmalarına engel olmalarını istedi. Bunu sağlarlarsa Kırım Hanlığı, Kefe ve Azak taraflarından Rus topraklarına saldırıların yapılmayacağını, Rus topraklarının her taraftan güven altında olacağını, fakat Don Kazaklarını zapt edemeyip denize çıkıp Osmanlı topraklarına zarar vermelerine engel olamazlarsa Tatar askerleri ve Kefe tarafinda bulunan askerlerinin Rus topraklarına akınlar yapıp intikam

\footnotetext{
15 Novoselskiy, s. 131-132.

16 Novoselskiy, s. 132.

17 Tihonov, s. 99.

18 Novoselskiy, 238.
} 
alacağını, ona göre hareket edilmesini, aradaki dostluğa uyarak Kazakların Osmanlı topraklarına saldırmamalarına dikkat göstermelerini istedi ${ }^{19}$.

IV. Murat'ın bu mektubu sonrası Çar Mihail Fedoroviç, 1635 yılının Mayıs ayında Kazaklara gönderdiği yazısında, Kazakları sultan ile arasındaki iyi ilişkileri bozmakla suçluyordu. Sultan ile arasında bir anlaşmazlık çıktığı takdirde bundan Kazakların sorumlu tutulacağını bildiren çar, yazısında ayrıca, Kazakların, Azaklarla anlaşmalarını, sultan ve Kırım ile barış içinde yaşamalarını istedi. Moskova Hükümeti, Kazakların özellikle Ulu Nogaylarla ilgilenmelerini, Onların, Don Nehri'nin Kırım taraflarına geçmelerine bütün kuvvetleriyle engel olmalarını, geçenlerin Astarhan'a getirilmesini, karşı gelenlerin ise cezalandırılmalarını istedi. Don Kazakları, tüm direnmelerine rağmen Nogayların göçlerine engel olamadılar. Nogay uluslarının göçleriyle İdil ve Don Nehirleri arasındaki çöller bomboş kaldı. Bu durum Azak'ın Kiçkene Nogaylarının desteğinden mahrum kalmasına ve Don Kazaklarının Azak'ı işgal etmelerine imkân yarattı ${ }^{20}$.

Aslında o tarihlerde Azak Kalesi sadece Nogayların desteğinden mahrum durumda değildi. Osmanlı Devleti ve Kırım Hanlığı da bu dönemde Azak'a destek veremeyecek bir durumdaydi. Litvanya-Lehistan ile 1634'te barış antlaşması imzalayan Osmanlı Devleti, İran ile büyük bir savaşın içine sürüklenmişti. Bu savaş sırasında İran ordusu, Gürcistan'da Osmanlılara karşı üstünlük sağladığı gibi Doğu Anadolu'dan Osmanlı topraklarına girmeyi de başardı. İran ile mücadele devam ederken, Erdel'de Rakoçi tarafından başlatılan bir halk ayaklanması çıktı. Osmanlı Devleti için sorunlar bunlarla sınırlı değildi. İran savaşına katılmayı reddeden Kırım Han'1 İnayet Giray, Nogay Tatarlarını da yanına alarak Kantemir Mirza'ya karşı sefere çıktı ${ }^{21}$. Sonrasında han, Kefe'de kendisini tehdit eden Kefe Paşası'nın üzerine yürüyerek Kefe'yi ele geçirdi. Böylece Azak Kalesi hem Osmanlı ordularının hem de Kırım Hanlığı ordularının korumasından ve ayrıca Nogay ordusunun destek siperinden mahrum kald $1^{22}$.

19 Başbakanlık Osmanlı Arşivi, Yabancı Arşivler Fonu, Rusya Federasyonu Arşivi, YB (1) $1 / 12$

${ }^{20}$ Novoselskiy, 238-241.

21 N. A. Smirnov, Rossiya i Turtsiya v XVI-XVII vv., Tom: II, Moskva 1946, s. 43;Tihinov, s. 100.Osmanlı hâkimiyetine muhalefette bulunan Kırım Hanı İnayet Giray, daha önce Mehmet ve Şahin Giray zamanında Osmanlı Devleti'nin, Kırım Hanlığı'na karşı desteklediği Mansuroğlu Nogaylarından Kantemir Mirza'yı Kırım'daki egemenliği için tehlikeli gördüğünden üzerine sefer düzenledi. Kantemir Mirza'ya karşı düzenlenen sefer ve Rakoçi'nin başlatmış olduğu ayaklanma için bkz. İsmail Hakkı Uzunçarş11, Osmanlı Tarihi, c. III, k1sım: II, Ankara 1982, s. 13-14, 60-61.

22 Smirnov, 43; Tihinov, s. 100; Uzunçarş1lı, s. 13-14. 
Bundan dolayı Osmanlı Devleti, Azak ve çevresini diplomatik yollarla koruyabilmek için faaliyete geçti. Sultan IV. Murat, bölgede oluşan boşluk ve karmaşanın yaratabileceği tehlikeleri ortadan kaldırmak için 1637 yılında Foma Kantakuzin'i Moskova'ya gönderdi. Beşinci defa Rusya'ya gönderilen Kantakuzin'e verilen görevler arasında, Don Kazaklarının son durumu hakkında bilgi toplaması da bulunuyordu. Ayrica Moskova'ya gelince de Çarlık Hükümeti'ni, Kazakların Azaklılarla savaşmasını yasaklaması yönünde ikna etmesi gerekiyordu. Don bölgesi üzerinden Moskova'ya gidecek olan Kantakuzin' in kendileri aleyhine diplomatik temaslarda bulunacağını bilen Kazaklar, yoğun karı mazeret göstererek, Onun, Moskova'ya gidişine engel oldular. Kantakuzin'in Don'da bulunduğu tarihten daha önce Kazaklar, Azak'ı alabilmek için hazırlıklarına başlamışlardı ${ }^{23}$.

\section{Don Kazaklarının Azak’ı İşgali ve Rusların Tutumu}

Azak Kalesi'ne yapılacak taarruz harekâtı kararı 1637 yılının Ocak ayında yapılan askeri mecliste alındı. Azak Kalesi'nin işgalinin zor geçeceğinin farkında olan Kazaklar, sefere tüm Kazakların katılması için emirler yolladılar. Emre uymayanların "kanun dışına çıkanlar" olarak ilan edilecekleri yönünde tehditlerde de bulunuldu. Lehistan baskısından kaçan Zaporog Kazaklariyla takviye edilen Don Kazakları, ataman Mihail Tatarinov önderliğinde 21 Nisan 1637'de Azak Kalesi'ni kuşattılar ve 18 Haziran 1637'de de kaleyi ele geçirdiler ${ }^{24}$.

Don Kazaklarının Azak’ı işgalleri Moskova, İstanbul, Bahçesaray, Esfahan $^{25}$, Varşova saraylarında oldukça büyük bir yankı yapt ${ }^{26}$. Bu işgal Osmanlılarda büyük bir şaşkınlık yarattı. Bu olay Osmanlıların endişesinin hiç de yersiz olmadığını kanıtlıyordu. Osmanlı Devleti'nin Kantakuzin'i Rusya'ya göndermesi, Azak Paşası'nın işgal öncesinde Moskova'ya göndermiş olduğu mektup ${ }^{27}$, onun, kuzeyden bir saldırı gelebileceği endişesi içerisinde olduğunu gösteriyordu. Osmanlıların bu dönemde İran ile giriştiği önemli mücadeleyi bir kenara bırakıp, Azak sorununu çözmesi pek mümkün

23 Tihinov, s. 101.

24 Tihinov, s. 102-103.

25 Don Kazaklarının Azak'ı işgallerinin İran'da sevinç ve mutluluk uyandırdığını düşünmek çok da yanlış olmasa gerekir. Osmanlı Devleti’nin yeni sorunlarla karşı karşıya gelmesi, güçlerinin bir kısmını o tarafa yönlendirme ihtimali İran'ın işine gelen bir durumdu. Bundan dolayı İran Hükümeti, Kazaklara elçilik heyetinin yanı sıra para yardımı da gönderdi. Ancak Kazaklara para götüren kervan Çerkeslerin yağmasına uğradı. A.V. Venkov, Azovskoe Sidenie, Geroiçeskaya Oborona Azova v 1637-1642 gg. Moskva 2009, s. 99.

26 Tihinov, s. 99.

27 Azak Paşasının göndermiş olduğu mektup için bkz. sayfa 8. 
değildi. Moskova'da bu haberin sevincin yanı sıra temkinli bir şekilde karşılandığı da muhakkaktı. Bu olayın iki ülkenin tarihçileri tarafından farklı bir şekilde yorumlandığını da ortaya koyalım.

Osmanlı tarihi yazarları, Don Kazaklarının Azak Kalesi'ni işgallerini değerlendirirken, Moskova Hükümeti’nin, Kırım Hanı'nın, Kantemir Mirza'ya karşı sefere çıktığını bildiğinden savunmasız kalan Azak'ı almaları için Kazakları teşvik ettiği iddiasında bulunurlar ${ }^{28}$. Rus yazarları ise Kazakların, Rusya'dan habersiz ve onların fikrini almadan Azak Kalesi'ni işgal ettikleri iddiasındadırlar ${ }^{29}$.

Azak Kalesi’nin işgalinde Rusların teşvik ve yardımlarının olup olmadığına dair sağlıklı bir değerlendirme yapabilmek için Rusya'nın o tarihlerde içerisinde bulunduğu siyasi durumu çok iyi analiz etmek gerekir. Yukarıda yapılan açıklamalarda da vurgulandığ 1 üzere, Rusya için bu tarihlerde en önemli sorun Smolensk sorunuydu. Bu sorun çözümlenmeden Rusya'nın güneyde aktif bir siyaset izlemesi düşünülemezdi. Hal böyle olunca güneyde barışın ve güvenliğin sağlanmasına en çok ihtiyaç duyduğu bir anda Kazakları, Azak Kalesi'ni almaları için yönlendirdiklerini düşünmek çok doğru olmasa gerekir. Rus kaynaklarının vurguladığı üzere Kazaklar, Rusların, Osmanlı Devleti ve Kırım Hanlığı'na karşı izledikleri siyaseti bildikleri için, Azak'1 işgal edeceklerine dair Ruslara bilgi vermemeleri muhtemeldir.

B. N. Florja, yapmış olduğu çalışmada bu konuya dair çok önemli bir saptamada bulunmuştur. B. N. Florja, çalışmasında, Rus Hükümeti'nin Kazakları Azak'1 almaları için kışkırttığına ve bu olayın Osmanlı Devleti'ne karşı hazırlanan bir saldırının planı olduğuna dair bir kanıt ya da belgenin olmadığını, Moskova Hükümeti'nin böyle bir plan içerisinde olsa Osmanlılara karşı savaş1 yürütmek için müttefik aramak zorunda kalacağını, müttefik olarak da ilk akla gelen devletin Lehistan olduğunu fakat bu yılların Rus-Leh görüşmelerinin dokümanlarında böylesi girişimlerin izlerine rastlanmadığını belirtir ${ }^{30}$.

Don Kazakları, Azak'a saldırma kararı aldıktan sonra, askeri güçlerinin ve teçhizatlarının yetersiz olmasından dolayı, Atamanları İvan Katorniy ve

28 Bkz. Naima Mustafa Efendi, Naima Tarihi, c. III, İstanbul 1281-1283, s. 322, Ahmet Cavit, Osmanlı-Rus İlişkileri Tarihi (Ahmet Cavit Bey'in Müntehebatı), Hazırlayan: Adnan Baycar, İstanbul 2004, s.125.

29 Lunin, s. 28-29; Novoselskiy, s.257; Tihinov, s. 101.

30 Boris Nikolayeviç Florya, "Osmanskaja İmperiya, Krım İ Stranı Vostoçnıy Evropı Vo Vtoroy Polovine 30-h-40-h gg. XVII v.”, Osmanskaja Imperija i Stranı Tsentralnoy, Vostoçnoy I Yugo-Vostoçnoy Evropı v XVII v. çast: I, Moskva 2001, s. 159. 
Timofey Yakovskiy'i yardım sağlamak için Moskova’ya gönderdiler. 1636 yılının Aralık ayından 1637 yılının Şubat ayına kadar Moskova'da kalan Kazak Atamanı İvan Katorniy ile 1637 yılının Mart'indan Mayıs'ına kadar Moskova'da bulunan Timofey Yakovskiy, Azak'a düzenlenecek saldırı hakkında Moskova Hükümetine hiçbir şey söylemediler ${ }^{31}$. Kazak Atamanı İvan Katorniy'in Moskova'da bulunduğu tarihlerde Azak Paşa's1 Moskova'ya bir mektup göndermişti. Paşa mektubunda, sultanın Moskova Çarını her zaman dostu olarak saydığından dolayı Azaklıların, Moskova Devleti'ne zarar vermelerini ve Kazaklara karşı harekete geçmelerini yasakladığını yazıyordu. Paşa mektubunda ayrıca çardan, Osmanlı elçisi Foma Kantakuzin'in kabul edilmesi için Don'a adamlarını göndermesi ricasında bulunup, Ataman Katorniy'in önderliğindeki Don Kazaklarının yaptıkları baskınlardan şikâyet ediyordu. Azak Paşası'na yazılan cevapta Moskova Hükümeti'nin, Sultanın dostluk ve sevgi mektubunu getirmekte olan Osmanlı elçisinin karşılanması için buzlar çözüldüğünde askerlerle birlikte bir asilzadesini göndereceği belirtiliyordu. Gönderilecek kişiye ayrıca, Don Kazaklarına Azaklılarla barışmaları, Foma Kantakuzin'i kabul edip serbest bırakmaları, denize çıkmamaları için "her türlü tedbirlerle" ikna etmesi görevi de verileceği yazıyordu ${ }^{32}$.

11 Mart 1637'de Stepan Mihayloviç Çirikov'a Don'a gitmesi için hazırlanması ve Osmanlı elçisine göz kulak olması emri verilmişti. Çirikov ile birlikte Don Kazaklarına 2000 ruble tutarında çarlık maaşı, 40 araba kumaş, top cephanesi olarak da 100 pud barut, 50 pud güherçile, 100 pud kurşun, 40 pud kükürt ve 84 küçük boydaki toplar için 50'şer top güllesi gönderildi. 20 Mayıs'ta Don'a gelen Çirikov, Kazakların Azak Kalesi'ni kuşatmaya gitmiş olduklarından dolayı yaşadıkları şehirlerde Kazakları göremediğini, kendisinden derhal top cephanesi-barut ve güllelerin teslim alınıp Azak'a gönderildiğini bildirdi. Bu rapordan sonra Moskova ile Çirikov arasındaki haberleşme koptu. Don'dan sağlıklı haberler gelmiyordu. Ancak 1637 yılının Temmuz ayının sonlarında Kazaklar, Moskova'ya bir mektup gönderdiler.

Kazaklar mektuplarında kendilerini Don Nehri çevresinden uzaklaştırmak isteyen Azaklılar üzerine saldırıya gittiklerinden Stepan Çirikov'un Don'da kimseyi bulamadığını, saldırının devam ettiği sırada Çirikov'dan Osmanlı elçisinin kabul edilmesi yönündeki çarın mektubunu aldıklarını belirtmektedirler. Mektubun devamında Kazaklar, Azak'1 kuşatmaları sırasında Kantakuzin'in Azak'a gönderdiği ulağı yakaladıklarını,

31 Lunin, , s. 28-29; Novoselskiy, s.257.

32 Smirnov, s. 44-45. 
ona işkenceler yaparak konuşturduklarını, kendisinin Kantakuzin tarafindan Azaklı insanlara gönderilmiş olduğunu, oradakilerin ise Osmanlı garnizonlarının konuşlandığı Kırım'dan, Temrük'ten ve Taman'dan yardım istemeleri gerektiğini belirttiğini, bundan dolayı da Osmanlı elçisi ve adamlarını kılıçtan geçirdiklerini yazdıktan sonra Azak'1 18 Haziran 1637'de ele geçirdiklerini yazdılar ${ }^{33}$.

Kazakların bu başarısı, Moskova Hükümeti'nin Osmanlı Devleti'ne karşı uyguladığ1 siyasete aykırı olduğu gibi, Osmanlı Devleti ile arasında istenmeyen olayların çıkmasına da sebep olabilirdi. Gerçektende 1637 yılının Eylül ayında Nureddin Saffet Geray, Rus topraklarına bir sefer düzenleyip, elçi olarak Hankul Bey'i Moskova'ya gönderdi. Saffet Geray bu elçiyle, bu seferi Osmanlı Sultanının fermanıyla yaptığını, Azak'ın geri verilmesine kadar da Rusya'ya sefer yapmaya devam edeceğini bildirdi. Moskova Hükümeti ise buna karş1lık, Azak şehrinin ele geçirilişinde hiçbir rolü olmadığını, bunu Kazakların kendi başlarına Moskova'nın fikrini sormadan gerçekleştirdiklerini ileri sürdü. Moskova Hükümeti, 26 Kasım ve 8 Mart tarihlerinde Kazaklara gönderdikleri mektuplarında, Saffet Geray'ın Rus topraklarına yaptığ 1 ve ileride de yapılacak herhangi bir akın için Kazakların sorumlu olduklarını bildirdi. 1638 yılının Nisan ayında Moskova'ya gelen Don Kazaklarının Ataman'1 Mihail Tatarinov, istenilen yardımlar yapıldığı takdirde son kişiye kadar Azak için savaşacaklarını, Moskova Çar'ına sadık olmakla birlikte Azak şehrinin ele geçirilişinin yalnız onları ilgilendiren bir mesele olarak kabul edilmesi gerektiğini belirterek bu şehrin sahibi olarak kalmak istediklerini söyledi. Ayrıca Ataman, Moskova Hükümeti'nden askeri bir destek değil, maddi ve mühimmat desteği beklediklerini bildirdi. Zaten Moskova Hükümeti Azak'a silahlı kuvvet gönderemezdi. Çünkü bu Osmanlı Sultanı ile aralarının açılmasına, hatta bir savaşın başlamasına sebep olurdu. Rusya bunu göze alamazdı. Fakat Kazakların Azak'ta kalmaları Moskova'nın menfaatineydi. Saffet Geray'ın Moskova topraklarına yaptığı akın, 1637-1641 yılları arasında Tatarların Rus topraklarına yaptıkları yegâne büyük akındı ${ }^{34}$. Bu nedenle Moskova Hükümeti, Kazaklara, Tatarlara karşı savaşmaları ve Azak'1 elde tutmaları için gerekli olan ekmek, barut, kurşun ve cephane yardımını düzenli bir şekilde yapt ${ }^{35}$. Ayrıca çar, Kazakların isteğiyle Ruslara, Azak ile serbest ticaret yapılması iznini de verdi ${ }^{36}$.

33 Smirnov, s. 45-48.

34 Novoselskiy, s. 257; 260-261.

35 Lunin, s. 38-39.

36 Tihinov, s. 104. 
Rus Çarı, Kazakların Azak’ı işgallerinden dolayı Osmanlı Devleti ile arasının bozulmaması için Sultan IV. Murat'a elçisiyle birlikte mektup gönderdi. Çar mektubunda şöyle yazıyordu: "Kazakların elçinizi öldürmüş ve Azak'1 ele geçirmiş olmalarından dolayı abimiz sayılan sizin bize kızgınlık ve kin beslememenizi isterdim. Çünkü onlar bu işi bizim iznimiz ve haberimiz olmadan yapmış olup, biz de bu insanlar için yaptıkları işlerden dolayı onları savunmak istemeyiz. Bu yüzden de sizinle olan ilişkilerimizi de bozmak niyetinde değiliz. Biliyoruz ki, eğer siz isterseniz onları muazzam gücünüzle bir saat içerisinde bile bozguna uğratırsınız. Biz ise sizinle sevgi ve dostluk içinde yaşamaya devam etmeyi arzuluyoruz". Moskova Hükümeti, Kazakların yapmış olduğu taarruzla hiçbir ilgisinin olmadığg yönünde açıklamalarda bulunmuştu. Rus Hükümeti, Kazaklara gönderdiği yazılarda, Osmanlılara tesadüfen de olsa esir düşen Kazakların, Azak'1 çarın emri ile değil, kendilerinin inisiyatifleri üzerine ele geçirmiş oldukları yönünde açılamalarda bulunmalarını istedi. Böylece Osmanlıların tüm şüphelerini yok etmek mümkün olabilirdi. Gerçeklerle tam olarak örtüşen bu görüşü, Kazakların sürekli akıllarında tutmaları isteniyordu ${ }^{37}$.

IV. Murat Bağdat seferine çıkmış olduğundan Rusya'ya cevabı Kaymakam Musa Paşa yazdı. Kaymakam dostça yazmış olduğu mektubunda, IV. Murat'ın, Kefe Beylerbeyinden, Kazakların Azak'1 Rusların izni ve isteğiyle işgal ettiklerini öğrenip buna inandığını, fakat elçinizle göndermiş olduğunuz mektuptan sonra Kazakların Azak'ı işgallerinden haberinizin olmadığına ve padişahımızın dostuna dost düşmanına düşman olduğunuza dair yaptığınız yeminlere itibar ettiğini bildirdi. Paşa mektubun devamında Ruslara sitemde bulunarak, Azak Kalesini ele geçiren Kazak eşkıyasının şaykalarını yakmaya, bulundukları yerleri dağıtmaya, onları Osmanlı topraklarına zarar vermeyecek hale getirmeye yeterli kuvvetleri varken ve Kazaklar üzerine asker gönderip onlardan Azak Kalesini alarak bize teslim etmeleri gerekirken bunu yapmadıklarını fakat geçen sene Leh Kralı'nın Özi'ye çıkan Kazaklar üzerine askerler gönderip onları bozguna uğrattıklarını belirtti. Rusların da dostluğa uyup Leh Kralı gibi Kazak eşkıyalarını ortadan kaldırmalarını istedi. Mektubun sonunda ise, Padişahın düşmanına düşman dostuna dost olduğu müddetçe Rusya'nın Padişahtan dostluk göreceklerini bildirdi $^{38}$. Bu mektup, Rus tarihçi Smirnov'un da belirttiği üzere, İran ile önemli bir mücadele içerisinde bulunan Osmanlı Devleti'nin Azak yüzünden meydana gelen sorunu barışçı yollarla çözmeyi istediğini ortaya koyuyordu ${ }^{39}$.

\footnotetext{
37 Tihinov, s. 104; Smirnov, s. 52-53.

38 BOA, YB (1) $1 / 15$

39 Smirnov, s. 54.
} 
Gerçekten de Osmanlıların içerisinde bulunduğu durum Azak'a hemen müdahale etmesine engeldi.

Hem İran savaşı hem de sultan değişikliği ${ }^{40}$ nedeniyle Azak'a sefer düzenleyemeyen Osmanlı Devleti, İran savaşının bitmesiyle 1641 yılında Kırım ordusuyla birlikte Azak Kalesini kuşattı. Bu kuşatmada Azak Kalesi çok tahrip olmasına rağmen, Kırım Hanı ile Osmanlı kumandanları arasında baş gösteren anlaşmazlıklar, ordu içerisinde bulaşıcı hastalıkların ortaya çıkması, barutun bitmesi ve kışın gelmesi gibi nedenlerle Osmanlıların kuşatmayı kaldırmalarıyla Azak, Kazakların elinde kalmaya devam etti ${ }^{41}$. Kuşatmanın kaldırılmasıyla Don Kazakları, Ataman Naum Vasilyev'i Moskova'ya göndererek, çarın, Azak'ı himayesi altına alması, kendilerine silah, erzak, insan yardımının yapılması ve Azak'a silahlı askerlerle komutanlar göndermesi ricasında bulundular. 2 Aralık 1641'de çar, Azak'taki durumu yakından incelemeleri için A. Jelyabuyskiy ve A. Başmakov'u 5000 ruble parayla Azak'a gönderdi. 1642 yılının 8 Mart günü incelemelerini tamamlayarak Moskova'ya dönen Jelyabuyskiy ve Başmakov, Azak Kalesi'nden geriye hiçbir şey kalmadığını, 11 kuleden ancak 3 kulenin kaldığını, onların da çok büyük tahribat gördüklerini ve kaleyi çeviren hendeğin tıkanmış olduğunu söyleyerek, Taşkale ve Toprakkale gibi kısımlarında tamamen yıkıldıklarını ve bundan dolayı bir onarım yapmanın imkânsız olduğunu bildirdiler ${ }^{42}$. Moskova Hükümeti, son kararın verilmesi için Ülke Meclisini topladı. Farklı sınıf temsilcilerinin katıldığ1 Meclis'te üyelerin bir kısmı Azak Kalesi'ni Kazaklardan teslim alarak, buranın Osmanlılara karşı kullanılması fikrini ileri sürmüşlerse de bu görüş mecliste kabul görmedi. Azak'1n tam manasıyla yıkılmış olması, savunması için gönderilecek askerlere dahi barınacak bir yerinin bulunmaması, Osmanlı ve Kırımlıların Azak’1 kurtarmak için Azak ve Rusya topraklarına sefere hazırlanmaları gerekçe gösterilerek, Azak'ın boşaltılmasına karar verildi. Bu karar 27 Nisan günü toplanan Boyarlar Meclisi toplantısinda, Ataman Naum Vasilyev'e ve 30 Nisan 1642 tarihli çarın fermanıyla da Azak'taki Kazaklara bildirildi. Çar, fermanında Kazaklara Azak'1 terk etmeleri nedenlerini yukarıdaki biçimde sıraladıktan

40 IV. Murat'ın ölmesiyle Osmanlı tahtına geçen I. İbrahim, Rus Çar'ına tahta çıktığını haber veren bir mektup gönderdi. Mektupta, iki ülke arasındaki dostluk ve yemin gereğince tahta çıktığının o taraflarda da bilinmesini isteyen I. İbrahim, Rusya ile eskisi gibi barış içinde yaşamayı istediğini bildirdi. BOA, YB (1) 1/17. Rus Çar'ı bu mektuba cevaben elçileriyle İstanbul'a bir mektup göndererek, Sultan İbrahim'i tahta çıkmış olduğundan dolayı tebrik etti ve Osmanlı Devleti ile barış içinde yaşamak istediğini bildirdi. Novoselskiy, 309-310.

41 Josef Von Hammer, Büyük Osmanlı Tarihi, c. V, Çeviren: Mümin Çevik, İstanbul 1998, s. 323; Naima, c. IV, s. 6; Lunin, s. 54-55.

42 Lunin, s. 57-60; Novoselskiy, s. 310. 
sonra, daha önce yaşadıkları bölgelere dönerlerse onlara maaş vermeye devam edeceğini, emrinin dinlenmeyip, Osmanlı ve Kırım ordusu gelene kadar Azak'tan ayrılmazlarsa, karşılaşacakları tüm zulümlerle kendilerinin sorumlu olacağını, Azak'1 terk etmemeleri durumunda hiçbir maaş ve yardım göndermeyeceğini bildirdi ${ }^{43}$. Bunun üzerine Kazaklar, Azak Kalesi'ni tahrip ettikten sonra boşalttılar ${ }^{44}$.

\section{Sonuç}

Rusya bu politikasıyla Karadeniz yönünde aktif bir siyaset izlemediğini ortaya koydu. Daha önce de belirtildiği gibi bu tarihlerde Rusya için önemli olan, Lehistan ile Smolensk sorunuydu. Smolensk şehrinin coğrafi olarak Moskova'ya yakınlığ 1 Rusya üzerinde bir bask1 oluşturmuş ve bu şehrin 1654'te alınışına kadar da Rusya ne batıda ne de güneyde aktif bir yayılma siyaseti izleyememiştir.

Osmanlı Devleti ve Kırım Hanlığı'nın Azak Kalesi’nin işgali süresince içerisinde bulundukları durum göz önüne alındığında, bu işgalle birlikte Karadeniz'in de ciddi bir tehlike içerisine düşme ihtimali vardı. Kazakların, maddi ve askeri anlamda imkânlarının sınırlı olması, Rusya'nın Lehistan tehlikesi nedeniyle güneyde barışı koruma politikası içinde olması bölgede ve Karadeniz'de daha büyük tehlikelerin yaşanmasını engellemiştir. Azak Kalesi'nin fethi Don Kazaklarının askeri gücünün hiçte hafife alınmaması gerektiğini de ortaya koymuştur. Osmanlı Devleti'nin Azak Kalesi gibi önemli bir kaleyi koruyamaması ve kalenin 5 yıl boyunca Kazakların elinde kalması onun, bir önceki yüzyıla göre gücünün azalmaya başladığını göstermesi bakımından da önemlidir. Bu olayın Osmanlı Devleti'ni prestij kaybına uğrattı̆̆ını söylemek de yanlış olmasa gerekir.

43 Venkov, s. 170-171.

44 Çar, Kazak Atamanı Osip Petrov'a yazmış olduğu 27 Temmuz 1642 tarihli mektupta, Kazaklara itaatleri ve Azak şehrini hızlı bir şekilde terk etmelerinden dolayı teşekkür etti. Burada şunu da belirtmek gerekir ki, Kazakların, Moskova Hükümeti'nin kararını kabul etmekten başka çareleri yoktu. Çar, mektubunda Kazaklara, eskisi gibi Moskovalı ve Osmanlı elçilerini karşılamaları ve uğurlamaları, Azak’taki insanlarla barış içinde yaşamaları, denize açılmamaları, Osmanlı köy ve kasabalarına saldırmamaları talimatını verdi. Çar mektubunda ayrıca, eskisi gibi askeri hizmete devam etmeleri karşılığında Onlara, maaş bağlayacağını da bildirdi. Akdes Nimet Kurat, Rusya Tarihi, Ankara 1999,s. 218; Popov, s. 51; Venkov, s. 173; Novoselskiy, s. 311. 


\section{Kaynakça}

Başbakanlık Osmanlı Arşivi, Yabancı Arşivler Fonu, Rusya Federasyonu Arşivi, YB (1) $1 / 12$, YB (1) $1 / 15$, YB (1) $1 / 17$

CAVIT, Ahmet, Osmanlı-Rus Illişkileri Tarihi (Ahmet Cavit Bey'in Müntehebatt), (Hazırlayan: Adnan Baycar), İstanbul 2004.

ÇEBOTAREV, B. V. - KAZAKOVA, L. M., "Azov-Gorod Krepkiy", Voprosı İstorii, No:8, Moskva 1967.

FLORJA, B. N., “Osmanskaja İmperija, Krım İ Stranı Vostoçnıy Evropı Vo Vtoroy Polovine 30-h-40-h gg. XVII", Osmanskaja Imperija i Stranı Tsentralnoy, Vostoçnoy I Yugo-Vostoçnoy Evropı v XVII v. Moskva 2001.

HAMMER, Josef Von, Büyük Osmanlı Tarihi, c. V, Çeviren: Mümin Çevik, İstanbul 1998.

İNALCIK, Halil, "Osmanl1-Rus İlişkileri”, Türk Rus İlişkilerinde 500. Yll (14911992), (Ankara 12-14 Aralik 1992), Ankara 1999.

Katip Çelebi, Tuhfetü'l-Kibar Fi Esfari'l Bihar, İstanbul 1329.

KURAT, Akdes Nimet, Türkiye Ve İdil Boyu (1569 Astarhan Seferi, Ten-İdil Kanalı ve XVI-XVII yüzyll Osmanll-Rus Münasebetleri), Ankara 1966.

KURAT, Akdes Nimet, Rusya Tarihi, Ankara 1999.

LUNIN, B.V., Azovskaya Epopeya (1637-1641), Moskva 1988.

Naima Mustafa Efendi, Naima Tarihi, c. III, IV, İstanbul 1281-1283.

NOVOSELSKIY, A. A., Borba Moskovskogo Gosudarstva S Tatarami V Pervoy Polovine XVII. Veka. Moskva, 1948.

NOVOSiLTSEV, A.P., "XV. Yüzyıl ile XVI. Yüzyılın İlk Yarısında Rus-Türk İlişkileri”, Türk Rus İlişkilerinde 500. Yll (1491-1992), (Ankara 12-14 Aralık 1992), Ankara 1999.

POPOV, M., “Azovskaya Oborona (Stranitsa iz İstorii Donskogo Kazaçestva XVII v.)", Istoriçeskiy Jurnal, No:3, Moskva 1995.

SMIRNOV, N. A., Rossiya i Turtsiya v XVI-XVII vv., Tom: II, Moskva 1946.

TíHONOV, Yu . A., "Azovskoye Sideniye”, Voprosl İstorii, No:8, Moskva Avgust 1970.

UZUNÇARŞILI, İsmail H., Osmanlı Tarihi, c. III, kısım: II, Ankara 1982.

VENKOV, A.V., Azovskoe Sidenie, Geroiçeskaya Oborona Azova v 1637-1642 gg. Moskva 2009. 